\title{
Kawasan Karst Tuban: Salah Satu Sisa Kehidupan Manusia Masa
}

Lalu

\section{R.r. Triwurjani}

Keywords: karst, cave, settlement, artifact, potential, distribution

\section{How to Cite:}

Triwurjani, R. (2001). Kawasan Karst Tuban: Salah Satu Sisa Kehidupan Manusia Masa Lalu. Berkala Arkeologi, 21(1), 1-14. https:// doi.org/10.30883/jba.v21i1.829

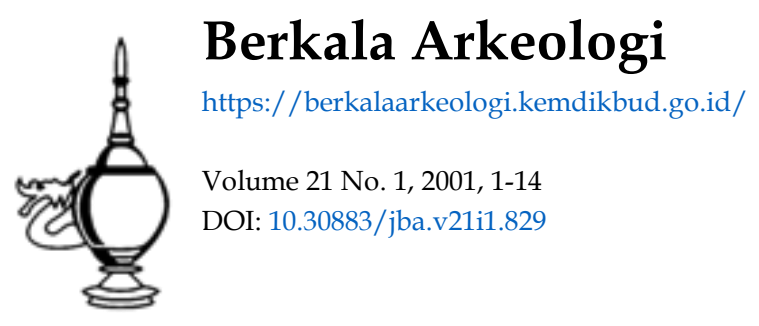




\title{
KAWASAN KARST TUBAN : SALAH SATU SISA KEHIDUPAN MANUSIA MASA LALU
}

\author{
Rr Triwurjani \\ (Pusat Penelitian Arkeologi)
}

\section{Pendahuluan}

Sejak awal Holosen, hunian gua menjadi semakin intensif dan meluas hingga berbagai pelosok Nusantara, tidak terbatas di pulau-pulau besar tetapi juga pulau-pulau kecil. Bahkan di daerah tertentu di mana sumberdaya lingkungan mendukung, seperti keberadaan pegubungan kapur yang menjadikan terbentuknya gua-gua dan ceruk, terjadi pemanfaatan maksimum oleh suatu komunitas dengan mengembangkan budaya yang khas. Komunitas semacam ini dijumpai di wilayah Gunung Sewu, Tuban, Bojonegoro, Basuki, Bangko, Kerinci, Sulawesi Selatan, Flores, Timor Timur dan Pegunungan Meratus (Simanjuntak, $t$ t).

Dilihat dari tingkat kehidupan manusia manusia masa lalu, maka kehidupan di gua dianggap sebagai kehidupan yang sedikit lebih maju bila dibandingkan pada masa jauh sebelumnya yang berpindah-pindah (nomaden). Kehidupan di gua ini sudah mulai menetap baik bersifat sementara maupun dalam kurun waktu yang cukup lama.

Apabila diamati dari bentang alamnya, maka gua ataupun ceruk memang dapat dijadikan sebagai tempat berteduh, baik dari cuaca (hujan, angin, badai, dsb) maupun dari gangguan binatang buas. Biasanya gua-gua dihuni pada kurun waktu yang cukup lama, meskipun tidak menutup kemungkinan digunakan sementara sebagai tempat persinggahan. Dengan kecenderungan sifat hunian yang cukup lama inilah, banyak aktivitas kehidupan yang dapat dilakukan oleh pendukung budaya gua. Beberapa segi dari aktivitass tersebut dapat ditelusuri dari peninggalan ataupun jejak-jejak dari budaya materi yang ditinggalkan, misalnya saja aktivitas kehidupan sehari-hari (profan) dan kegiatan upacara yang bersifat suci (sakral).

Simanjuntak (1995) mencoba mengklasifikasikan kehidupan gua ini kedalam 4 (empat) kelompok berdasarkan budaya materinya, yaitu kelompok Hoabinh yang dicirikan oleh alat batu masif, kolompok serpih bilah, kelompok industri tulang dan kelompok lukisan gua. Keempat kelompok budaya terdapat pada gua dan ceruk sebagai tempat hunian dan kegiatan lainnya.

Penelitian di 5 (lima) daerah kecamatan di Kabupaten Tuban telah memperlihatkan adanya bukti-bukti kehidupan gua pada masa lalu. Permasalahan yang mengemuka adalah kenyataan bahwa tidak semua gua-gua tersebut digunakan, ditempati atau 
mengandung sisa-sisa kehidupan manusia masa lalu; sekalipun gua-gua tersebut berada dalam gugusan karst yang sebagian besar diantaranya memang mempunyai kandungan arkeologis. Dengan demikian dapat diduga pula telah dilakukan serangkaian pertimbangan ataupun pilihan-pilihan sebelum suatu gua akan dihuni. Apabila benar demikian maka dilihat dari studi kawasan yang menyoroti pada pola pemukinan, maka pola pemukiman gua belum bisa dijadikan acuan pola perilaku keletakan hunian, seperti pola pemukiman pada umumnya, yaitu linear, mengelompok, ataupun menyebar. Hal ini disebabkan pemilihan gua yang pernah berlangsung kebanyakan berdasarkan ataupun disesuaikan dengan kondisi bentang alam yang tersedia. Kemampuan manusia dalam mengolah dan memahami lingkungan dikenal sebagai adaptasi. Adaptasi itu sendiri adalah merupakan hasil dari interaksi antara manusia dengan alam dan antara manusia dengan manusia, baik secara fisik maupun kimiawi di dalam lingkungan sekitarnya (Moran, 1979:4-8). Prinsipnya adalah bahwa setiap makhluk hidup, baik organisme, manusia, hewan, tumbuh-tumbuhan, ataupun lainnya selalu memberi tanggapan ('respon') kepada unsur-unsur karakteristik dan fungsi alam dimana mereka tinggal. Pada dasarnya manusia selalu ingin mengembangkan dirinya agar dapat hidup layak. Berbagai cara dilakukan manusia dalam mengatasi bermacam tantangan lingkungan dimanapun, termasuk juga pada komunitas penghuni gua, khususnya komunitas penghuni gua di kawasan kasrt Tuban. Dari hal seperti ini mengemuka pertanyaan, faktor apa yang mendorong komunitas manusia masa lalu sampai di tempat ini?, serta faktor setempat (intern) apa yang memungkinkan terselenggaranya kehidupan gua seperti itu di kawasan karst Tuban?. Hal-hal tersebut di atas sudah tentu mempunyai relevansi terhadap penelitian arkeologi, khususnya berkenaan dengan pemilihan lokasi dan bagaimanan manusia masa lalu berinteraksi dengan lingkungan dimana ia tinggal. Gambaran ini dapat pula menunjukkan perilaku ataupun cara-cara hidup manusia masa lalu.

\section{Deskripsi Analitis}

Sejarah geologi daerah Tuban telah dimulai pada kala Miosen. Pada kala ini terjadi proses sedimentasi yang membentuk satuan batu gamping. Secara regional daerah Tuban dimasukkan ke dalam zona Rembang yang berumur Miosen bawah hingga Miosen tengah. Satuan batuan penyusun di kawasan karst Tuban didominasi oleh batu gamping karst yang mengandung fosil-fosil Pelecypoda, Foraminifera dan Gastropoda. Batuan tersebut berwarna putih segar hingga coklat keabu-abuan, sedangkan yang telah mengalami pelapukan memperlihatkan warna coklat muda hingga coklat tua. Satuan gamping karst Tuban ini berumur Miosen.

Dari hasil survei di kawasan karst Tuban telah terpilih secara random 14 gua, yaitu gua-gua yang mengandung tinggalan arkeologis, yang meliputi 5 (lima) kecamatan di 
wilayah Kabupaten Tuban. Gua-gua tersebut antara lain:

\section{A. Gua Terus}

Gua ini terletak di Kecamatan Montong, Kabupaten Tuban. Sampai sekarang gua ini masih dianggap keramat dan masih digunakan sebagai tempat utnuk memuja. Benda yang dipuja adalah stalaktit yang terdapat di gua tersebut. Menurut keterangan dari Bapak Suwardjan (q 55th), penilik kebudayaan Kabupaten Tuban, di gua ini pernah ditemukan nekara perungggu yang berukuran cukup besar, yang sekarang disimpan di museum Mpu Tantular Surabaya. Temuan lainnya adalah 3 (tiga) kapak perunggu dan 1 (satu) tombak terbuat dari perunggu juga, yang sekarang disimpan di museum Kambang Putih, Kabupaten Tuban. Dari hasil survei berhasil diidentifikasi adanya sisa fauna yang terdiri Filum Chordota, Kelas Aves. Dari Filum Moluska ditemukan dari Kelas Pelecypoda dari Famili Arcides.

\section{B. Gua Gede}

Terletak Di Kecamatan Montong Sebelah Utara pada gugusan gamping. Secara fisik, gua ini mempunyai ruangan yang cukup luas dan sangat baik untuk tempat hunian. Temuan yang ada berupa sisa fauna yangterdiri dari gigi geraham yang berasal dari kelas Mamalia (Bovidae) dan ada pula dari Famili Rodentia. Temuan lainnya adalah fragmen tulang rahang bawah dan rusuk dari jenis Rattus sp, Famili Muridae. Sedangkan temuan sisa Moluska terdiri dari jenis siput darat mewakili kelas Gasthropoda.

\section{Gua (Song) Prahu}

Gua ini pernah diteliti oleh tim dari Balai Arkeologi Yogyakarta yang dipimpin oleh Goenadi Nitihaminoto. Gua ini berupa ceruk yang tinggi dan salah satu ruangan pada ceruk tersebut terdapat ruangan yang menyerupai haluan perahu dengan langit-langit yang rendah. Oleh karena itu gua ini disebut juga Gua Prahu. Di depan gua ini mengalir sungai kecil. Diduga sungai tersebut mungkin tergolong sungai yang besar. Diseberangnya terdapat tebing yang tinggi dan pada beberapa bagian sudah hilang. Menurut van Heekeren gua ini pernah dihuni oleh orang Prasejarah pada masa Neolitik 7000 SM.

Menurut Goenadi (1983:76-78) berdasarkan analisis sementara terhadap temuan kereweng yang dihubungkan dengan konteks temuan lainnya di gua ini, dapat diketahui bahwa song Prahu merupakan tempat hunian sekaligus juga sebagai tempat penguburan sejak tradisi bercocok tanam hingga tradisi perundagian secara berturutturut. Baru pada abad $15-16 \mathrm{M}$ gua ini berganti fungsi sebagai situs upacara. 
Hasil survei yang ada masih menunjukkan adanya temuan sisa fauna yang antara lain berasal dari Filum Chordata ditemukan sisa hewan berasal dari Ordo Artiodactyla (Famili Bovidae),dan Ordo Carnifora (Famili Canidae). Jenis tulang dari kedua Filum di atas berupa fragmen tulang dari gigi. Adapun Filum Moluska yang ditemukan adalah dari Kelas Pelecypoda, Famili Veneridae. Selain itu juga ditemukan cangkang kerang. Dilihat dari bentuk cangkang dan pengamatan secara megaskopis terhadap sisa cangkang tersebut diketahui bahwa sisa cangkang tersebut merupakan bahan mentah ('raw materials') pembuat alat kerang. Temuan lainnya adalah berupa tatal batu dan beberapa alat serpih.

\section{Gua Suci}

Gua ini terletak di Desa Wangun, dusun Suci, Kecamatan Palang. Gua ini terbentuk akibat penambangan gamping secara besar-besaran sehinmga terjadi ruangan yang seolah-olah merupakan suatu bangunan. Bentuk ruangan memiliki luas yang bervariasi. Sebagai misal yang berukuran $10 \times 10 \mathrm{M}$ dengan ketinggian kurang lebih 15 M. Pada salah satu dinding tersebut terdapat tulisan Jawa Kuno yang berangka tahun 1278 Saka, yang bersamaaan dengan masa pemerintahan Hayam Wuruk di Kerajaan Majapahit (keterangan lisan Drs. Machi Suhadi). Tulisan lainnya tidak dapat terbaca karena tidak jelas. Pada bagian-bagian dinding yang lain terdapat lukisan yang tidak jelas bentuknya (seperti bentuk wayang, akan tetapi secara keseluruhan belum jelas).

\section{E. Gua Gembul}

Gua ini merupakan ceruk besar bertingkat dua, memiliki halaman luas di depannya dengan tumbuhan yang besar dan rindang. Halaman ini dahulu diperkirakan merupakan lembah sungai atau endapan sungai. Pada salah satu bagian sisinya terdapat dinding gamping yang tegak lurus, diperkirakan sebagai hasil dari proses geologis berupa geseran horizontal. Ceruk tersebut diduga bekas dinding yang kemudian terkikis dan membentuk ceruk bertingkat. Di atasnya terdapat ceruk dengan ketinggian $3 \mathrm{~m}$ dari permukaan tanah, dan dibentuk undakan sehingga mirip dengan bagunan punden berundak. Undak pertama menempel ke dinding. Pada undak ini terdapat dipan/tempat tidur yang ditutupi kain putih, sehingga sepintas selalu menyerupai makam. Sedangkan undak lainnya tidak ditemukan apapun, hanya dipergunakan sebagai tempat semedi.

Setiap undakan dibuat pagar kayu yang ditutupi kain putih. Gua ini sampai sekarang digunakan sebagai tempat pemujaan/dikeramatkan. Di sekitar ceruk pertama ditemukan sisa hewan darat dan moluska yang telah mengalami fosilisasi sehingga sulit untuk dapat diidentifikasi lebih lanjut. Sedangkan sisa hewan lain ditemukan dari Filum Chordata berupa fragmen tulang. 


\section{F. Gua Butul}

Gua ini terletak pada deretan bukit gamping yang memanjang. Gua ini merupakan gua horizontal dengan lorong-lorong pada bagian atas. Secara fisik gua ini sudah teracak akibat aktivitas manusia masa lalu berupa tatal, fragmen tulang, fragmen karang dan kereweng. Artefak batu yang ditemukan terdiri dari serut samping 2 buah, serut punggung atau serut tebal 3 buah, alat batu inti, alat tulang 3 buah, gurdi 3 buah, mata panah 1 buah, kapak penetak, 25 serpih (flake), 2 buah gerabah hias gores dan sisa kerang. Alat tulang yang ada diperkirakan merupakan lancipan. Sedangkan sisa fauna yang ditemukan terdiri atas Filum Chordata dan Filum Moluska. Filum Chordota dari kelas Mamalia, Ordo Artiodactyla, Famili Bovidae. Beberapa fragmen tulang menunjukkan ciri terbakar. Selain itu ditemukan pula sisa fauna dari Ordo Rodentia, Famili Muridae (Rattus sp) berupa tulang paha. Jenis hewan Ordo Primata, Famili Cercopithecidae (Macaca sp) yakni berupa fragmen tulang rahang bawah.

\section{G. Gua Cilik}

Letak Gua Cilik berdekatan dengan gua Butul, masih dalam deretan bukit Gamping yang sama dan berjarak kurang lebih $100 \mathrm{M}$ dari gua Butul ke arah barat. Di gua ini ditemukan tulang dan kerang yang sudah menjadi semen, bahkan ada indikasi jenis batu bara muda.

\section{H. Gua Peteng}

Gua ini masih sederetan dengan gua Butul dan gua cilik. Letaknya agak tinggi dan mempunyai atap gua yang tebal/tinggi. Luas gua ini $10 \times 2 \mathrm{~m}$ dan tinggi kurang lebih $10 \mathrm{~m}$. Lantai gua tidak rata dan banyak terdapat lorong-lorong, pada bagian-bagian tertentu terdapat lubang-lubang akibat penambangan gamping dan juga pengambilan kotoran kelelawarnya sebagai bahan pupuk. Pada salah satu lorong diatas terdapat lubang berbentuk persegi ukuran $1 \times 1 \mathrm{~m}$, kedalaman kurang lebih $2 \mathrm{~m}$. Di dalam bekas galian tersebut ditemukan fragmen tulang hewan.

Jenis-jenis hewan yang ditemukan di dalam gua berasal dari Filum Chordota dan Filum Moluska. Filum Chordota dari kelas Mamalia, Ordo Carnivora, Famili Canidae,Genus Canis (Serigala) memiliki kelengkapan jenis tulang, yaitu tulang tengkorak,tulang rahang bawah, tulang belikat,tulang rahang atas,tulang rusuk,tulang atlas, tulang telapak tangan, tulang paha, tulang kering, tulan rusuk, tulang panggul, tulang betis, tulang pergelangan kaki, tulang jari, dan gigi. Adapun Filum Moluska yang ditemukan berasal dari kelas Pelecypoda, terdiri dari Famili Archidae, dan Famili Veneridae. 


\section{Gua Sumur}

Gua ini merupakan ceruk yang menghadap ke Barat Daya. Pada bagian dalam ceruk tersebut terdapat lubang bekas penambangan gamping. Luas gua ini $4 \times 2 \mathrm{M}$,dengan tinggi gua $1 \mathrm{M}$ Temuan yang ada hanya berupa fragmen geraham babi, tulang hewan,dan karang yang sudah tersementasi gamping.

Pada bagian depan/halaman Gua Sumur ditemukan fosil tulang yang tertanam di dalam tanah. Belum diketahui seberapa jauh fosil tulang tersebut tertanam di dalam karena sulit untuk di keluarkan begitu saja tanpa suatu metode yang sistimatis.

\section{J. Gua Bale}

Letak gua Bale masih sederetan dengan gua Sumur. Keadaan gua ini sudah hancur sama sekali akibat penambangan batu gamping. Akan tetapi indikasi budaya masa lalu yang masih tertinggal pada dinding berupa kerang dan tulang yang mengalami proses fosil. Di sebelah kiri pintu masuk Gua Bale ditemukan sementasi tulang gigi yang rata menempel pada dinding, kelihatan bekas dipangkas akibat proses penambangan gamping.

\section{K. Gua Gede}

Gua ini terletak di sebelah Gua Bale dengan kondisi yang sama (rusak) akibat aktivitas manusia masa sekarang. Temuan berupa tulang dan kerang yang tersemen pada gua ini merupakan indikasi adanya hunian pada masa lampau. Gua Gede menghadap ke Utara (laut).

\section{Gua Pawon}

Gua Pawon berada pada lokasi yang sama, $50 \mathrm{M}$ dari Gua Butul, merupakan ceruk dengan luas $3 \times 6 \mathrm{M}$, dalam (horisontal) $3 \mathrm{M}$ dan tinggi $2 \mathrm{M}$. Gua ini merupakan satu gugusan dengan Gua Sumur, Bale, dan Gede. Kondisinya juga sudah rusak akibat penambangan batu gamping dan juga penambangan batu bara pada bagian depan gua. Onggokan tulang dan kerang yang sudah tersementasi juga ditemukan pada bagian sebelah kiri pintu masuk gua sebagai indikasi bekas hunian masa lampau. Gua ini masih mengalami proses pembentukan dapat dilihat dari adanya air yang masih menetes.

Sisa hewan yang ditemukan dari Filum Chordata dan Filum Moluska. Filum Chordata dari kelas Mamalia, Ordo Artiodactylia meliputi Famili Bovidae (Bos), Capridae (Capra), dan Ordo Rodentia, Famili Muridae (Rattus sp). Sisa hewan ini berupa gigi geraham dan fragmen tulang rahang atas, serta ruas tulang belakang. Beberapa di 
antaranya telah mengalami proses fosil. Adapun Filum Moluska yang ditemukan terdiri dari kelas Gastropoda (Famili Potamididae) dan kelas Pelecypoda (Famili Archidae,Veneridae). Dari kelas Gastropoda maupun Pelecypoda, jenis Moluska yang diperoleh dari habitat air payau dan air laut belumpur.

\section{Gua Akbar}

Gua ini sangat luas dan besar, dengan lorong-lorong yang cukup dalam. Pada bagian tertentu Gua ini masih dalam proses pembentukan. Luas $200 \mathrm{~m}^{2}$, tinggi $\pm 10 \mathrm{M}$, menghadap ke Barat Laut, dengan kelembaban $90 \%$, $\mathrm{pH}$ tanah 6 , dan suhu $26-28^{\circ} \mathrm{C}$. Gua Akbar terletak di belakanmg pasar,oleh karena itu tidak heran bila sebagian besar gua berisi sampah pasar. Dari segi fisiknya gua ini memiliki potensi untuk obyek pariwisata. Sekeliling gua ditumbuhi tanaman liar (semak belukar) juga ditumbuhi pohon nangka,pisang,pepaya,jagung dan lain-lain. Binatang yang ditemui di gua ini dari jenis, kelelawar, bunglon, kalajengking,semut merah dan nyamuk.

Jenis sisa hewan yang ditemukan di dalam gua berasal dari Filum Chordata dan Filum Moluska. Filum Chordota dari kelas Mamalia menempati urutan kuantitas yang dominan, meliputi Ordo Artiodactyla, Ordo Canivora dan Ordo Rodentia.

Dari Ordo Artidactyla ditemukan Famili Bovidae (Bos, dan Ovis sp),sedangkan dari Ordo Carnivora berasal dari Famili Canidae (Canis). Ordo Rodentia yang ditemukan berasal dari Famili Muridae (Rattus sp). Kelas hewan lain dari Filum Chordata adalah Kelas Aves, Ordo Galliformes (Gallus sp.). Keseluruhan hewan di atas berupa gigi dan fragmen tulang.

\section{N. Gua Bagong}

Gua Bagong terletak di Desa Bejagung Kec. Semanding. Gua ini masih merupakan kompleks Gua Butul dengan kondisi yang parah. Gua ini boleh dikatakan tinggal reruntuhan akibat proses penambangan Gamping sehingga sulit menetukan bentuk Gua yang asli. Yang tampak sekarang adalah gua buatan bukan alam lagi.

\section{Pembahasan}

Dilihat dari keletakan gua-gua di Kecamatan Montong Kabupaten Tuban, sebenarnya 14 gua yang telah di survai ini merupakan sebagian kecil saja dan ratusan gua(q 150 gua) yang tersebar merata di seluruh kawasan tersebut. Ke empat belas gua ini adalah sampel saja, yang diambil secara acak (random), yang terdapat di 5 (lima) Kecamatan yang terdapat di daerah Tuban. Gua-gua lainnya sebagian besar, meskipun masih bisa dikenali, akan tetapi sudah merubah fisik gua itu sendiriseagai akibat penambangan

Berkala Arkeologi Th. XXI (1)

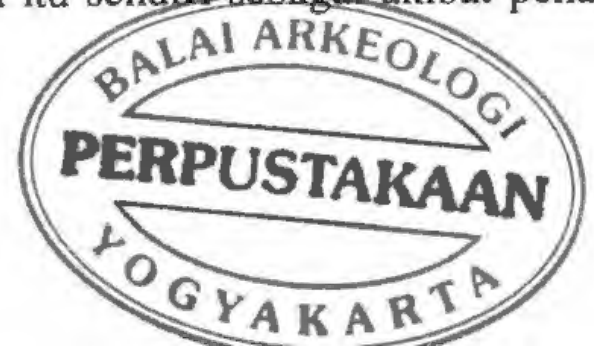


gamping secar besar-besaran yang dilakukan manusia masa kini. Akan halnya gua suci di Kecamatan Palang, terdapat tulisan Jawa Kuno pada dinding gua yang menuhjukkan angka tahun 1278 Saka. Selain itu juga ditemui lukisan yang belum diketahui bentuknya. Menurut keterangan lisan dari Bapak Machi Suhadi (1990), tulisan tersebut berasal dari masa pemerintahan Hayamwuruk, Kerajaan Majapahit. Melihat lingkungan fisiknya sebenarnya gua ini merupakan gundukan tanah yang pada bagian bawahnya banyak mengandung gamping. Ruang-ruang di bawah tanah ini terjadi sebagai akibat dari proses penambangan gamping yang sedemikian rupa (sistimatis) yang menunjukkan bahwa penambangan tersebut dikelola oleh sutau perusahaan besar yang dilakukan secara bertahap dan dalam jangka waktu yang cukup panjang. Dilihat dari keletakannya, tulisan tersebut yang terletak di dinding gua sebelah atas, tampak bahwa tulisan tersebut baru dipahatkan kemudian setelah ditambang. Bentuk tulisannya pun diduga bukan tulisan dari orang-orang yang terbiasa menulis tulisan kuno, penuh dengan coretan-coretan baru (asli tapi tidak orisinil). Keduanya menunjukkan bahwa tulisan ini berasal dari masa kemudian dan mungkin saja tidak mempunyai peran yang begitu penting dalam sistem budaya yang dimaksud.

Deretan gua-gua di daratan tinggi Kecamatan Semanding, bisa disebut sebagai kompleks gua,apalagi kondisi dan karakteristik gua-guanya relatif sama. Gua-gua tersebut antara lain: Gua Butul, Gua Cilik, Gua Peteng, Gua sumur, Gua Pawon, Gua Gede dan Gua Bale. Gua-gua di sebelah Selatannya berjauhan letaknya, yaitu Gua song Prahu, Gua Gede dan Gua Akbar. Adanya kelompok-kelompok gua ini adalah didasarkan atas keletakkan alamiah gua tersebut pada bentang lahannya.

Adanya temuan sisa moluska yang dijumpai pada hampir semua gua di kawasan ini, menggambarkanbahwa penggunanan sumberdaya alam atas hewan tersebut menunjukkan adanya intensitas pemakaian yang tinggi, terlebih lagi keletakan gugusan karst ini sangat dekat dengan laut. Dari sisa-sisa kerang yang dalam kondisi 'sementit' dan bercampur dengan temuan lainnya, dapat diperkirakan bahwa sisa-sisa tersebut adalah merupakan bagian dari sampah dapur. Banyaknya kerang yang ditemukan dapat menjelaskan pula, selain kerang tersebut dikonsumsi sebagai sumber bahan makanan yang berprotein tinggi, kerang-kerang ini juga digunakan sebagai alat. Alat dari jenis hewan ini disebut juga sebagai alat kerang. Temuan lain yang juga mendominasi di kawasan ini adalah alat serpih dan tatal batu. Temuan-temuan tersebut dapat menunjukkan pula bahwa komunitas masyarakat kawasan karst Tuban pernah menggunakan sumberdaya alam di sekitarnya secara intensi, terutama pada pemanfaatan moluska dan bahan batuan yang digunakan sebagai bahan untuk membuat alat. Fenomena ini sebenarnya merupakan hal yang wajar, dimana manusia menggunakan sumberdaya alam tersedia, demi kelangsungan hidupnya. Apabila komunitas manusia cukup lama tinggal di suatu tempat tersebut, maka dengan demikian penggunaan sumberdaya alam di sekitarnya pun juga cenderung intensif. 
Gambaran ini dapat dibuktikan dengan banyak (adanya) sisa kehidupan atau aktivitas manusia yang dikenal dengan sisa budaya materi yang ditinggalkan.

Pada gua-gua di kawasan karst Tuban, meskipun sebagian besar kondisinya sudah hancur akibat penambangan gamping ataupun eksplorasi secara besar-besaran dan dalam kurun waktu yang cukup lama, namun masih dapat dikenali adanya sebaran temuan ataupun sisa-sisa kahidupan manusia masa lalu, hampir di seluruh kawasan tersebut. Kendatipun kondisinya sudah tidak utuh lagi dan banyak sekali bersifat fragmentaris. Oleh karena itu penelitian yang berkenaan dengan pola hunian di kawasan ini masih relevan dengan apalagi dalam usaha-usaha untuk merekonstruksi cara-cara hidup manusia masa lalu. Sebaran gua-gua yang mengandung tinggalan arkeologis ini, selanjutnya dapat dianggap sebagai sisa hunian komunitas manusia masa lalu di kawasan karst Tuban.

Akan tetapi sebaran hunian atas gua tersebut yang dibuktikan dari peninggalan budaya materinya belum cukup disebut sebagai cara-cara hidup yang normatif, yaitu suatu hunia yang biasanya mempunyai pola, baik itu pola linear, mengelompok ataupun tersebar. Karena hal ini sangat terkait dengan penelitian lokasi terhadap gua-gua yang ada, dimana gua-gua tersebut memang merupakan satu gugusan kawasan karst. Lingkungan sekitar gua seperti laut yang terletak di sebelah Barat deretan gua-gua tersebut dan adanya temuan sisa-sisa kerang menunjukkan bahwa masyarakat yang hidup pada masa itu tergantung juga pada hasil-hasil laut, adalah merupakan gambaran dari proses adaptasi komunitas penghuni gua. Adanya temuan gerabah, temuan sisa fauna, dapat juga menunjukkan bahwa selain sumberdaya alam dari laut mereka juga memanfaatkan sumberdaya dari darat. Dengan bahan makanan yang tersedia dan keadaan lingkungan alam yang menunjang, misalnya dalam penyediaan bahan mentah pembuat alat tidak mustahil bahwa masyarakat masa lalu penah memilih dan menghuni kompleks gua-gua di kawasan karst ini sebagai tempat beraktivitas.

Apabila dilihat dari cara-cara hidup yang dapat ditelusuri lewat peninggalannya maka kehidupan manusia di gua-gua ini termasuk dalam kategori kelompok serpih bilah yang pada dasarnya memanfaakan gua-gua dan ceruk sebagai tempat tinggal dan kegiatan lainnya. 


\section{Penutup}

Dari data yang ada dapat dijelaskan bahwa kawasan Karst Tuban khususnya Kecamatan Semanding, Montong, Plumpang dan Rengel pernah berperan bagi kehidupan manusia masa lalu, keberlangsungan hidup manusia penghuni gua-gua tersebut ditunjang oleh sumberdaya alam sekitarnya yang terdiri dari dataran dan laut. Hal yang terakhir dibuktikan dengan adanya temuan sisa-sisa kerang.

Dengan demikian dapat dikatakan bahwa daerah Tuban kaya akan tinggalan arkeologis meskipun temuan-temuan yang ada banyak terdiri dari temuan lepas, tersebar tidak merata di wilayah ini. Hal ini sebagian besar disebabkan oleh penambangan gamping secara besar-besaran dan berlangsung dalam waktu yang cukup lama.

Keadaan ini sesungguhnya sangat memprihatinkan karena aktifitas ini berdampak pada hilangnya atau rusaknya jejak arkeologis. Mengingat pentingnya tinggalan arkeologis sebagai latar belakang budaya masyarakat Tuban, maka perlu dilestarikan keberadaan gua-gua tersebut yang masih bisa diselamatkan.

Hal ini tidak saja berguna bagi kepentingan arkeologi (budaya) tetapi juga melindungi penduduk sekitarnya dari kegiatan penambangan yang dapat membahayakan, seperti tanah longsor, tata guna lahan yang berubah total seperti misalnya tidak terdapat lagi kantong-kantong air yang biasanya tersimpan di daerah Karst yang sangat berguna bagi kehidupan manusia sepanjang masa. 


\section{KEPUSTAKAAN}

Anonim, 1989 "Kawasan Karst Tuban" Kumpulan Makalah Seminar Sehari WALHI-HIKESPI, PALAWA Univ. Atmajaya Yogyakarta.

Bambang Budi Utomo, 1982 "Hasil Penelitian di daerah Tuban, Jawa Timur". Rapat Evaluasi Hasil Penelitian Arkeologi, Cisarua Puslit Arkenas Jakarta.

Bunyamin Dharma, 1988, Siput dan Kerang Indonesia, Jakarta: Sarana Graha.

Hole, Frank dan Robert Heizer, 1977 Prehistoric Archaeology A Brief Introduction. New York: Holt, Rinehart, and Wilson Inc.

Butzer, Karl W., 1990 Archaeology as Human Ecology: Method and Theory for a Contextual Approach, Cambridge University Press.

Moran, E.F., 1979 Human Adaptability: An Introduction to Ecological Anthropology, North Sctuate, MA: Duxbury.

Nitihaminoto, Goenadi, 1983 Hasil Analisis Sementara Kreweng Song Prahu, Tuban, PIA III, Ciloto, Jakarta: Puslit Arkenas.

Schmid, Elisabeth, 1972 Atlas of Animal Bones for Prehistorians, Archaelogist and Quarternary Geologist. London: Elsevier

Simanjuntak, Truman, tt Sejarah Hunian Gua-gua di Nusantara dan Asia Tenggara dalam Gunung Sewu sejak 12000 Tahun Yang Lalu, Jakarta.

1995 Cave Habitation During the Holocene Period in Gunung Sewu, Aspect of Indonesia Archaeology, No. 18, Jakarta: Puslit Arkenas.

Sumarmahadi, 1979 Tinjauan pada survei gua di daerah Kabupaten Tuban Propinsi Jawa Timur, Proyek Penelitian penggalian Purbakala, Depdikbud Yogyakarta.

Triwurjani, Rr., dkk, 1990 Laporan Penelitian Survei Bidang Arkeometri di Kawasan Karst Tuban, Kabupaten Tuban, Provinsi Jawa Timúr, (tidak diterbitkan), Jakarta: Puslit Arkenas. 


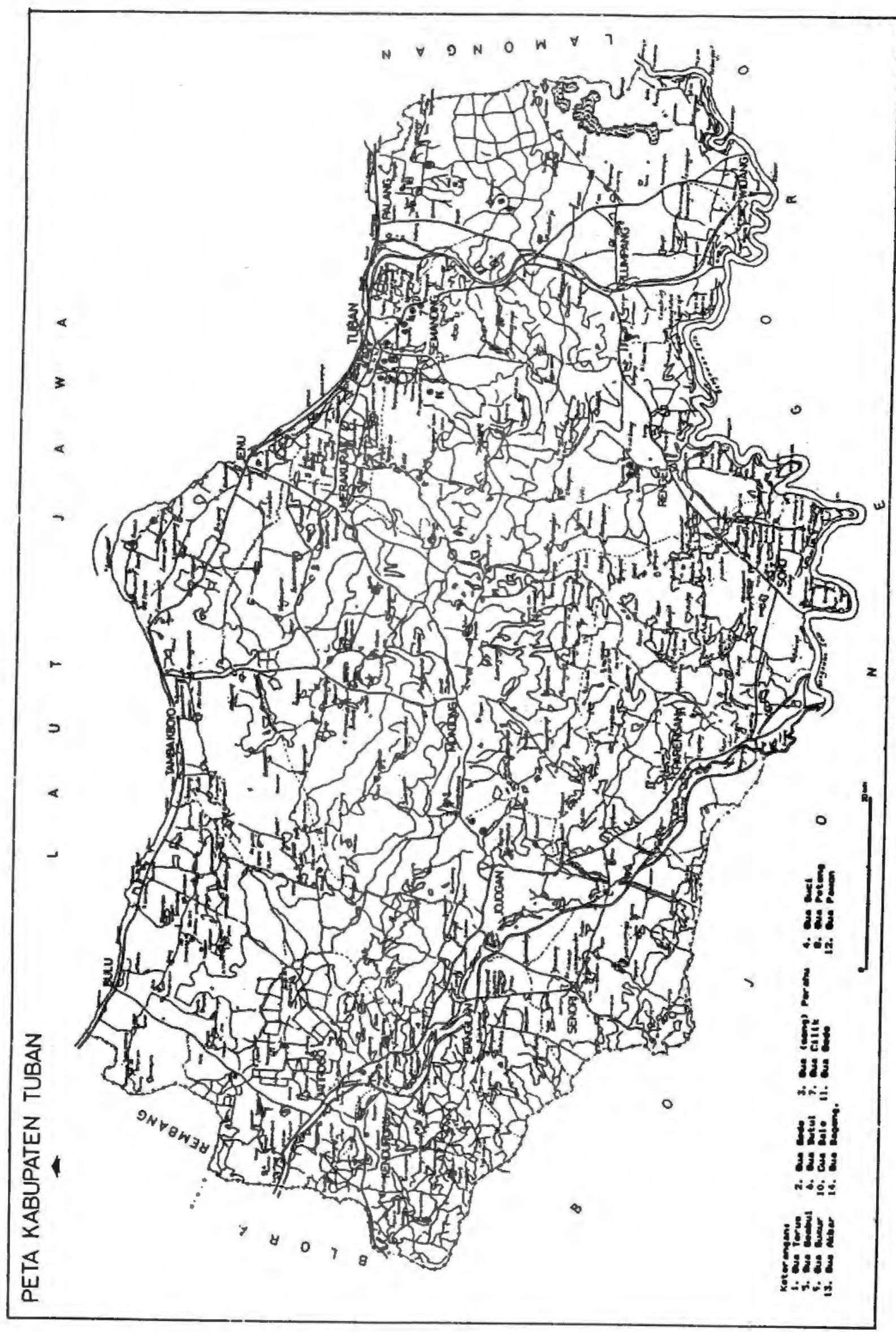




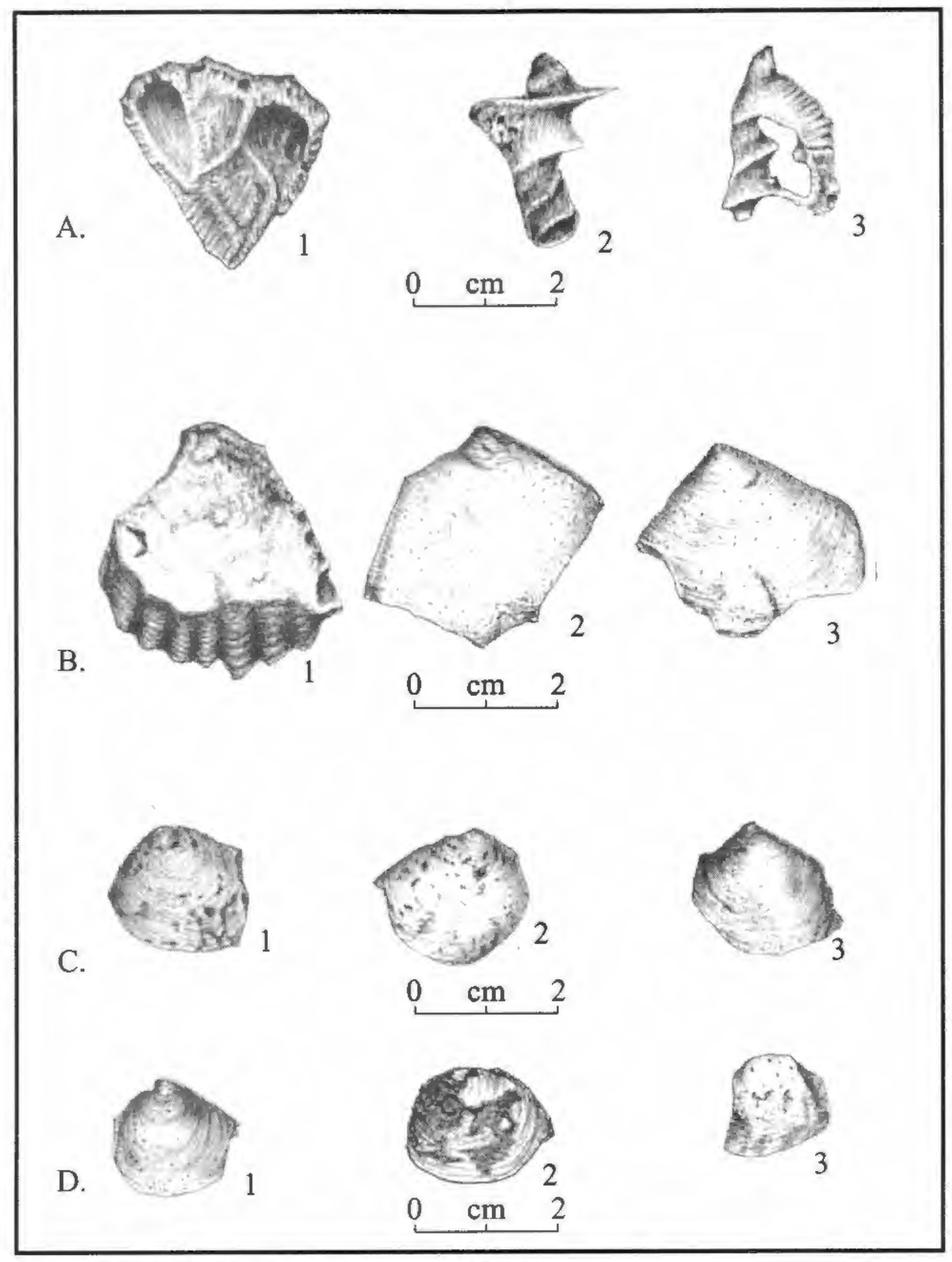

Gambar 1. Beberapa sampel sisa moluska dari kawasan karst Tuban 


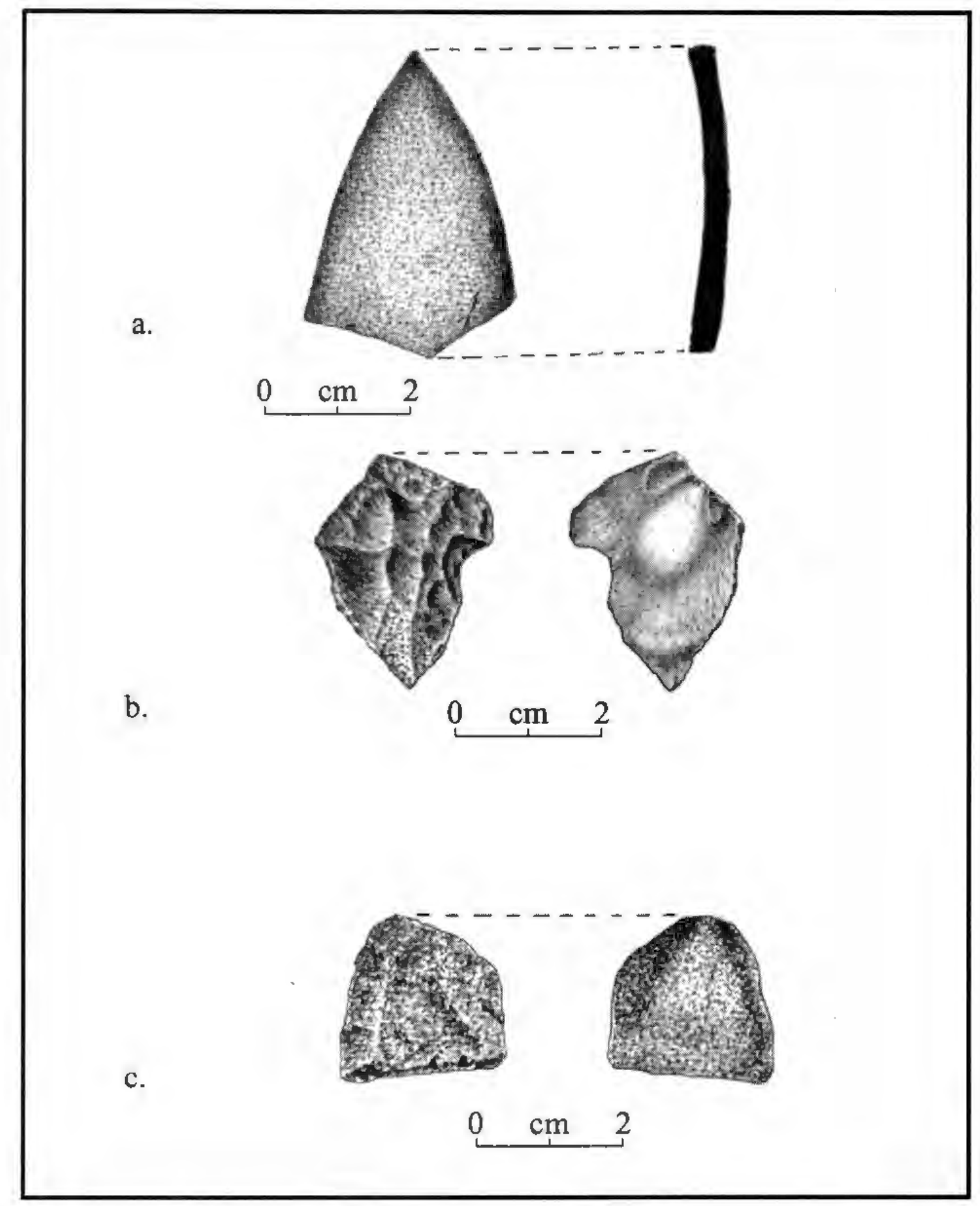

Gambar 2. Temuan artefak kawasan karst Tuban

a. Tembikar b. Alat batu serpih c. Alat batu bilah 